\title{
An Overview of the Civil Procedure and Court System of Netherlands
}

\author{
Xhemile Saliu \\ Faculty of law \\ International Balkan University \\ Email: xhemile.saliu@ibu.edu.mk \\ North Macedonia
}

\section{ABSTRACT}

When it comes to Dutch law, the initiation of civil litigation, there are just a few cases in the Netherlands. This is due to the harmonized Dutch culture. Therefore, compared to other European countries, the number of lawyers and judges per capita in the Netherlands is small. In this scientific paper, we will make an overview of the civil judicial organization, the types of civil proceedings, the obligation to represent the civil cases in the court through a lawyer, legal aid and also in more detail we will focus on the main stages of the civil trial as well as the conditions that must be met before initiating civil proceedings.

We will analyze in detail the fact that in the Dutch Law, the defendant may deny the right to judicial reconciliation with the plaintiff, before initiating the proceedings and that it is also preferable in Dutch Law, that the opposing party is summoned to fulfill its obligations within a certain period. If without respecting this method, the court procedure is initiated, the court costs may be attributed to the initiator of the procedure, i.e the plaintiff. Except for proceedings before judges from subordinate regions in Dutch law, the general rule is that the proceedings must be presided over by the plaintiff's attorney (procurator litis) and by a lawyer selected from the list of attorneys registered with the Association. In this scientific paper, we will also pay special attention to the temporary legal protection and special procedures and we will also focus on the judgments and legal remedies in Dutch law.

\section{KEYWORDS: initiation of the civil litigation, civil judicial organization, types of civil proceedings, main stages of the civil trials, legal remedies in the Dutch law.}

\section{A. General Judicial Organization}

Although the Kingdom of the Netherlands is a small country with about 16 million inhabitants, it is a European country that has a rich and important history for international trade. Considering the initiation of civil litigation, we have relatively few cases in the Netherlands. This is due to the harmonized Dutch culture (model polder) ${ }^{1}$. Therefore, compared to other European countries, the number of lawyers and judges per capita in the Netherlands is small ${ }^{2}$.

There are 19 regional courts (Rechtbank) in the country, which have civil, criminal, and administrative courts, 5 appellate courts (Gerechtsof), and a higher court (Hoge Raad). In the Netherlands there is a three-tier judiciary; also the regional courts (there are judges from subordinate regions) $)^{3}$, above them the courts of appeal and the Supreme Court ${ }^{4}$. All regional courts are divided into four parts: civil, criminal, administrative, and cantonal sections. Judges from subordinate regions are involved in the structure of regional courts, which preside over civil and criminal cases.

Cases up to 5,000 euros (small claims) and regardless of their value business cases, lease cases, sales, and agency disputes, are handled by judges from the subordinate regions of the regional courts located in the structure of the regional courts. All other proceedings are directed (conducted) directly

\footnotetext{
1 Jan de Vries - sc.paper: The Netherlands and the polder model: questioning the polder model concept; BMGN- Low Countries Historic

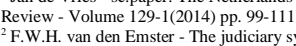

${ }^{2}$ F.W.H. van den Emster - The judiciary system in the Netherlands, 2020 - A book; page 5-16.

Philip Langbroek- sc.paper: Organization Development of the Dutch Judiciary, between Accountability and Judicial Independence; at International Journal For Court Administration | April 2010; page 1- 11. The article can be foun

${ }_{4}^{4}$ J. Uzman, T. Barkhuysen \& M.L. van Emmerik- sc.paper: The Dutch Supreme Court: A Reluctant Positive Legislator? At: Electronic Journal of Comparative Law, vol. 14.3 (December 2010), http://www.ejcl.org; page 1-35.
}

by the regional courts in the legal sectors. The legal sectors remain trained on certain specialized topics. The trial in the regional courts is conducted by a single judge, but the hearings are conducted by a panel (commission) of three judges. ${ }^{5}$.

\section{B. Contested and Out-Contested Procedure}

In Dutch jurisprudence, there are two types of court proceedings. The first court procedure is the contentious one, which begins with the submission of a summons by the competent officials and ends with a certain decision. In this trial, hearings are held. The non-contentious procedure starts with the request for initiating the procedure, and which is applied in cases of individual and family law. The request is portrayed by the competent officials and the opposing party is notified of the request. In this procedure, the decision is not final $^{6}$.

\section{Obligation of Representation Through the Lawyer}

In regional courts both parties; which means that both the plaintiff and the defendant are obliged to be represented by a lawyer or an authorized person however, in trials before judges from subordinate regions there is no such obligation. The only difference between the two procedures mentioned above is that in the contentious procedure there is an obligation of representation by an authorized person.

In the non-contentious procedure which in the regional courts begins with the submission of the request, it is inalienable that only the party initiating such procedure is

Judicial Organisation Act; Act of 18 April 1827 on the composition of the judiciary and the organisation of the justice system Neitherland; page 1-55; (Text applicable on 22/2/2008); Online Verzion at : https://www.rechtspraak.nl/SiteCollectionDocuments/Wet${ }^{6}$-dendre-Rechterlijke-Organisatie_EN.pd

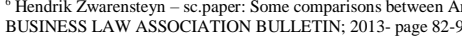




\author{
E-ISSN: 2469-6501 \\ VOL: 7, ISSUE: 12 \\ December/202 1 \\ DOI: http://dx.doi.org/10.33642/ijbass.v7n12p6 \\ https://creativecommons.org/licenses/by/4.0/
}

represented by the lawyer, while for the opposing party there is no such obligation. In proceedings with judges from subordinate regions, in cases of contentious or non-contentious proceedings, the plaintiff and the respondent may participate in person. ${ }^{7}$.

\section{Legal Aid}

According to the Law on Legal Aid, if the monthly amount of income of the parties is less than 2,000 Euros, there is a possibility to receive legal aid from the state. The party who loses the dispute is obliged to pay the costs of the court ${ }^{8}$.

\section{MAIN PHASES OF THE TRIAL}

\section{A. Conditions to Be Fulfilled Before Initiating the Court Procedure}

It is not necessary to warn the defendant before the proceedings begin. Because the defendant may deny the right to judicial conciliation with the plaintiff, before initiating the proceedings, the opposing party should be summoned to fulfill its obligations within a certain period. If without respecting this way, the court procedure is initiated, the court costs may be attributed to the initiator of the procedure, ie the plaintiff.

Except for proceedings before judges from subordinate regions, the general rule is that the proceedings should be conducted by the plaintiff's lawyer (procurator litis) ${ }^{9}$ and by a lawyer selected from the list of lawyers registered with the Association of Lawyers, in the place where the procedure takes place. The power of attorney of the plaintiff fulfills the official duties of the procedure and at the same time assists in the documentation, in the implementation of the court remarks, and the regulation of the judicial relations. ${ }^{10}$

\section{B. Initiation of The Proceedings and Trial}

The trial begins with a request to the court. The request made by the representative by proxy (Lawyer) of the plaintiff is sent to the competent body for submission and verification of claims. The competent body will set a date for holding a preliminary hearing and will send an invitation to the plaintiff and to the respondent. In addition, this competent body will set a date for the opposing party (the respondent) on which this party will implement its defense. When the parties will be heard by the judge during a single hearing, the court will make a preliminary ruling.

The request for initiating the procedure contains a date, on which date the request will be submitted to the court and also this request for initiating the procedure contains a detailed description of the lawsuit.

In addition, evidence and eventual witnesses will have to be included in this request.

From 1 January $2002^{11}$, as an important feature, which should contain the request for initiating the procedure, is also the counter-claims of the defendant, of course, if they are known. The purpose of this is to make the judgment flow as quickly and focused as possible.

\section{Giving The Answer by The Defendant}

If the defendant will be represented by a representative by proxy and if he initiates counter-proceedings, then the power of attorney of the plaintiff prepares a request for initiation of proceedings and this request must be submitted to the court within 6 weeks and at the same time to the document where the answer to the request is given, the power of attorney of the plaintiff must be signed.

After answering the request made with which the court-civil procedure has been initiated and after initiating the counter-procedure if the judge does not deem it necessary for the parties to submit their requests for replies and duplicates, sets a date for the preliminary hearing. This situation only works in extremely complex cases.

At the preliminary hearing, the parties must be present together with their representatives.

At this hearing, the judge encourages the parties to reconcile ${ }^{12}$ and sets a date for the issuance of a decision or to collect documents as evidence or to refer to witness statements or to experts, to make a preliminary decision ${ }^{13}$.

\section{Preparations Before the Session (Preparatory Phase)}

Institute: Discovery, which is known in the tradition of the Anglo-American (Common Law) legal system, does not exist in countries where the Continental European System predominates. However, to predict how the court proceedings will proceed in the advanced stages, the regional court may be required before the trial to examine the means of proof such as; witnesses or experts.

Also, the institute of data disclosure (disclosure), as is the case with the disclosure of evidence, is unknown to the Dutch judiciary, but with the introduction of a new article in the Law on Procedural Law, which is important from the aspect of issuing a judgment, regulates the obligation for the procedural parties to present the events completely and accurately. However, in this regard, it is not foreseen that the court should impose sanctions. If this task is not performed, the judge will achieve the desired result within the limits of his assessments $^{14}$

\section{E. Preliminary Sessions and Participations}

The procedural parties present their evidence based on the documents in court in writing. Evidence can be made by all means. The most important means of proof are evidence-based evidence, witness testimony, and examinations of qualified experts. In some cases, even the documents drafted by notaries are considered as established evidence ${ }^{15}$.

\section{F. Temporary Legal Protection and Special Procedures}

In Dutch law there is a procedure, the so-called temporary detention procedure (Kort geding), which exists in connection with the measures of the temporary legal protection 


\author{
E-ISSN: 2469-6501 \\ VOL: 7, ISSUE: 12 \\ December/202 1 \\ DOI: http://dx.doi.org/10.33642/ijbass.v7n12p6 \\ (c) $\underset{B Y}{(i)}$ \\ https://creativecommons.org/licenses/by/4.0/
}

of property and in the court of appeal in Amsterdam, which is the court of the first instance where is tried on special cases of private trade, in which special measures are applied. Temporary detention is a measure that is implemented very often.

Indeed, with the implementation of the temporary detention which became a way of a speedy trial, depending on the urgency of the case, the trial may end in a few days or a week. In most proceedings, the judgment rendered by the judge from the regional court also completes the entire court proceedings. However, after some cases, there are cases when proceedings are initiated through a regular court procedure ${ }^{16}$.

\title{
G. Judgments and Legal Remedies
}

As a rule, the courts of the first instance, in terms of their judgments, are subject to control in civil court proceedings, the value of which is 1,750 euros and above. It is not possible to appeal judgments on proceedings, the value of which is below the above amount.

The party who loses the case in whole or in part or when the judgment is pronounced against the procedural party, has the right to appeal the judgment rendered. ${ }^{17}$.

The appeal period for the judgment rendered is three months counting from the date of notification. The Court of Appeals, on the other hand, exercises all its powers and makes its decision on the case (Devolutive effect of appeal). In other words, the Court of Appeals has the authority to review events and correct legal omissions. It is even possible to decide on cases that have become the subject of a court of the first instance, but no court decision has been taken on them.

The appeal of the judgments regarding the monetary amounts delays the execution (execution) of the judgment. However, the courts of the first instance may authorize the provisional execution of the judgment. If the parties appeal against the judgment of the court of the first instance, it is not possible to decide for the party who appealed against the judgment (reformation in peius). Can be appealed ${ }^{18}$ judgments may be appealed, brought in a speedy court procedure (kort geding).

In a situation where omissions exist, the court negotiates with both parties and corrects the decision. If it is determined that a judgment has been erroneously brought to the detriment of one of the procedural parties and if after the judgment brought there is evidence, which evidence before the judgment was concealed in order not to be brought before the court, then the court may order the injured party to request the annulment of the judgment.

In the judgments of the courts of the first instance and in the judgments of the appeal where the appeal is closed, three months after the rendering of the judgment, one can move towards the appeal against the judgment. The appeal does not postpone the execution ${ }^{19}$.

\section{Court Costs}

Court costs in the Netherlands are not as high as in England and America. However, in the Netherlands, there is no provision that all court costs must be paid by the losing party. Usually, the court costs charged by the lawyers are higher than those set by the court.

These costs, if not clearly defined in the contract, or if not listed by the court, cannot be claimed by the opposing party. In civil-legal proceedings, according to the value of the dispute, the fixed court costs are paid when the civil-court procedure is initiated. ${ }^{20}$.

\section{CONCLUSION}

In terms of judicial organization in the Netherlands, there are 19 regional courts (Rechtbank), which in their structures have civil, criminal, and administrative courts, 5 courts of appeal (Gerechtsof), and a higher court (Hoge Raad). There is a three-tier judiciary in the Netherlands; also the regional courts (there are judges from subordinate regions), the appellate courts, and the Supreme Court. All regional courts are divided into four parts: civil, criminal, administrative, and cantonal. Judges from subordinate regions who preside over civil and criminal cases are engaged in the structure of regional courts. While when talking about various civil proceedings, in the non-contentious procedure which in the regional courts begins with the submission of the request, it is inalienable that only the party initiating such a procedure is represented by the lawyer, while for the opposing party there is no such obligation. In proceedings with judges from subordinate regions, in cases of contentious or non-contentious proceedings, the plaintiff and the respondent may participate in person.

In Dutch civil law, as regards the initiation of civil proceedings, from 1 January 2002, an important feature, which must contain the requirements for initiating proceedings, is the counter-claims of the respondent, of course, if they are known. The purpose of this is to make the trial run as fast and focused as possible. In Dutch law, it was also concluded that the institute - disclosure of data and documents (disclosure), as is the case with the disclosure of evidence, is unknown to the Dutch judiciary, but with the introduction of a new article in the Law of civil procedural of Netherlands, which is important from the point of view of rendering a judgment, regulates the obligation for the procedural parties to present the events completely and accurately.

However, in this regard, it is not provided that the court should impose sanctions. If this task is not performed, the judge will achieve the desired result within the limits of his assessments. What is worth noting from the analysis made is the fact that, in fact, with the implementation of the temporary ban which became a way of a speedy trial, depending on the urgency of the case, the trial in Dutch law may end for a few days or a week. In most of the proceedings, the judgment

MAASTRICHT EUROPEAN PRIVATE LAW INSTITUTE WORKING PAPER No. 2014/03, page 3-15.The paper can be downloade without charge from the Social Science Research Network at 


\author{
E-ISSN: 2469-6501 \\ VOL: 7, ISSUE: 12 \\ December/2021 \\ DOI: http://dx.doi.org/10.33642/ijbass.v7n12p6 \\ (c) (i) \\ https://creativecommons.org/licenses/by/4.0/
}

which is rendered by the judge in the regional court also completes the entire judicial procedure.

As for court costs in the Netherlands, they are not as high as in England and America. However, in the Netherlands, there is no provision that all court costs must be paid by the losing party. Usually, the court costs charged by the lawyers are higher than those determined by the court. These costs, unless previously clearly stated in the contract, or if not listed by the court, may not be claimed by the opposing party.

\title{
Bibliography
}

Jan de Vries - sc.paper: The Netherlands and the polder model: questioning the polder model concept; BMGN- Low Countries Historical Review - Volume 129-1 (2014) pp. 99-111.

F.W.H. van den Emster - The judiciary system in the Netherlands, 2020 - A book; page 5-16.

Philip Langbroek- sc.paper: Organization Development of the Dutch Judiciary, between Accountability and Judicial Independence; at - International Journal For Court Administration | April 2010; page 1- 11. The article can be found at: https://www.researchgate.net/publication/286091447

J. Uzman, T. Barkhuysen \& M.L. van Emmerik- sc.paper: The Dutch Supreme Court: A Reluctant Positive Legislator? At: Electronic Journal of Comparative Law, vol. 14.3 (December 2010), http://www.ejcl.org; page 1-35.

Judicial Organisation Act; Act of 18 April 1827 on the composition of the judiciary and the organisation of the justice system of Neitherland; page 1-55; (Text applicable on 22/2/2008); Online Verzion at

: https://www.rechtspraak.nl/SiteCollectionDocuments/Wet-op-de-Rechterlijke-Organisatie_EN.pdf

Hendrik Zwarensteyn-sc.paper: Some comparisons between Anglo- American Common Law and Dutch Civil Law, at AMERICAN BUSINESS LAW ASSOCIATION BULLETIN; 2013- page 82-95.

G.M. van den Broek \& Liesbeth F.H.Enneking - sc.paper: Public Interest Litigation in the Netherlands - A Multidimensional Take on the Promotion of Environmental Interests by Private Parties through the Courts; Article in

Utrecht Law Review · page 77-79- Volume 10, Issue 3 (June) 2014 | URN:NBN:NL:UI:10-1-115833; http://www.utrechtlawreview.org

Mathias Reimann General Reporter, University of Michigan- sc.paper: Cost and fee allocation in civil procedure- National Report for the Netherlands, version of 31, march 2011 by prof.dr. M.B.M.Loos-University of Amsterdam, the Netherlands-International Academy of Comparative Law 18th World Congress Washington D.C. July 21-31, 2010, page 1-9.

Ben Schuijling- a book- Chapter 7- Representation, power of Attorney and Mandate- Introdution to Dutch Law, Published by: Kluwer Law International B.V. PO Box 3162400 AH Alphen aan den Rijn, march 2016- page 117-122.

Dutch ( Neitherlands ) Civil Code- Book 3 Property law in general ; Title 3.3 Procuration (power of attorney); from 3: 60 to 3:79.

Dwi Handayani- sc.paper:Legal Principes of Evidence on Civil Cases in Public Judiciary; page 1-17; at Hang Tuah Law Journal, volume 1; Issue 1; April 2017.

Thomas De Weers- sc.paper: Case Flow Management Net-Project - The Practical Value for Civil Justice in the Netherlands; International Journal for Court Administration; Vol.8, No.1; 2016, from page 1-11.

Rhee, C.H. van - LOCUS STANDI IN DUTCH CIVIL LITIGATION IN COMPARATIVE PERSPECTIVE-MAASTRICHT EUROPEAN PRIVATE LAW INSTITUTE WORKING PAPER No. 2014/03, page 3-15.The paper can be downloaded without charge from the Social Science Research Network at http://www.ssrn.com

Dutch Civil Code-Article ; 87, 88, 131, 152 , 157, 166, 232, 1:235; 4; 7:405, paragraph 2. 